\title{
Dorota Degen, Polityka wydawnicza w sferze nauki w latach 1944-1959, Wydawnictwo Naukowe Uniwersytetu Mikołaja Kopernika, Toruń 2014, ss. 262
}

\footnotetext{
Opuris publikowana w 2014 r. za sprawą Wydawnictwa Naukowego UMK książka autorstwa Doroty Degen zatytułowana Polityka wydawnicza w sferze nauki w latach 1944-1959 to z pewnością jedna z ciekawszych, spośród opublikowanych w ostatnim czasie pozycji o charakterze interdyscyplinarnym. Z tych względów praca spotka się z zainteresowaniem nie tylko ze strony bibliologia i socjologa, ale też historyka, politologa czy naukoznawcy. Licząca 261 stron nietypowego formatu $(22,7$ x 14,8 cm) dysertacja podzielona została na trzy zasadnicze części poprzedzone Wprowadzeniem i podsumowane Zakończeniem, a uzupełnione ponadto bibliografią, spisem tabel i wykresów oraz indeksem osobowym. Poszczególne części zrębu głównego to Tradycje naukowego ruchu wydawniczego i koncepcje powojennej polityki wydawniczej (rozdział I), Budowa polityki naukowej wobec wydawnictw (1949-1952) (rozdział II) i Utrwalenie nowego modelu polityki wydawniczej w latach 1953-1959 (rozdział III). Uwieńczeniem każdego z wymienionych rozdziałów stały się krótkie prezentacje osób, które miały szczególny udział w kreowaniu nowej polityki wydawniczej w odniesieniu do książki naukowej, a należeli do nich Jerzy Borejsza, Adam Bromberg i Eugenia Krassowska.

Dzięki lekturze omawianego dzieła czytelnik zapozna się z sytuacją wydawniczą w sektorze nauki jeszcze w okresie dwudziestolecia międzywojennego. Okazuje się, że w tym czasie przedstawiciele nauki polskiej mogli liczyć na względną swobodę w zakresie prowadzonych przez siebie badań. Poszczególne instytucje, zwłaszcza uczelnie wyższe i organizacje
} 
społecznego ruchu naukowego, nie tylko miały możliwość decydowania o własnych poczynaniach, ale też aktywnie uczestniczyły w kształtowaniu podstaw prawnych swego funkcjonowania. Suwerenność ta z kolei owocowała rosnącą liczbą publikacji. Lata 1939-1945 to czas, kiedy naukowe organizacje mogły działać wyłącznie w podziemiu. Tylko nieliczne przygotowane do druku pozycje doczekały się wówczas realizacji, część z nich ujrzała światło dzienne dopiero po zakończeniu działań wojennych, część zaś nigdy nie została opublikowana. Ten trudny okres to również czas planów na powojenną przyszłość - liczono na pełną swobodę badawczą i porozumienie między związanymi z działalnością naukową podmiotami wydawniczymi w celu stworzenia jednego planu, uzależnionego od najpilniejszych potrzeb środowiska naukowego.

Niestety rzeczywistość okazała się inna. Wprawdzie pierwsze lata po zakończeniu okupacji przypominały nieco sytuację sprzed 1939 r. - wśród wydawców dominowali prywatni przedsiębiorcy i oficyny katolickie, prężnie też odradzał się społeczny ruch naukowy, jednak swoboda ta była systematycznie ograniczana. Wiążące się z tym zagrożenia dostrzegali przedstawiciele PAU, którzy w sposób szczególny zwracali uwagę na konieczność zapewnienia nauce odpowiednich środków niezbędnych do umożliwienia jej nieograniczonego rozwoju i akcentowali potrzebę zwolnienia z cenzury publikacji naukowych. Jednak reprezentanci nowych władz zamierzali nadać idącym zmianom całkiem inny kierunek. Ich celem było stworzenie jednej centralnej instytucji odpowiedzialnej za planowanie i nadzorowanie badań naukowych na wzór radzieckiej Akademii Nauk. Autorka omawianej książki znakomicie ukazała sposób, w jaki powoli, ale systematycznie wprowadzano decyzje władz w sferę kultury i nauki oraz przejmowano kontrolę nad drukiem, w wyniku czego środowisko naukowe zostało niemal całkowicie uzależnione od aparatu państwowego, zaś naukowe publikacje stały się narzędziem ideologicznej walki na „froncie nauki”.

Decydującym krokiem w opanowaniu przez władze komunistyczne sytuacji w zakresie druku książki naukowej, było powołanie w 1951 r. Polskiej Akademii Nauki i utworzenie Państwowego Wydawnictwa Naukowego. Jednocześnie rozwiązano dwie najprężniej działające organizacje społecznego ruchu naukowego: PAU i Warszawskie Towarzystwo Naukowe. Pozostałe organizacje o zbliżonym charakterze zostały podporządkowane PAN. Tej ostatniej powierzono również czołowe drukarnie naukowe w Polsce, w ten sposób stała się nadrzędną instytucją na rynku książki naukowej.

Pewne zmiany przyniósł 1953 r., kiedy to m.in. nasiliły się głosy krytyki pod adresem wydawanych przez wyższe uczelnie, a sterowanych przez 
komunistyczne władze zeszytów naukowych. Uzależnienie ich od PWN wydłużenie czasu realizacji, znikoma promocja i dystrybucja - wiązało się z małą popularnością i raczej negatywną ich oceną. Fakt ten sygnalizował, że przyjęty system pozostawiał wiele do życzenia i przyczynił się do wprowadzania od 1956 r. decentralizacji, w wyniku której zwrócono uczelniom zawłaszczone wcześniej uprawnienia do ogłaszania drukiem własnego dorobku.

Początki rozkładu wprowadzonego w Polsce po 1945 r. systemu dostrzec można było już w 1954 r., a wraz z odwilżą, jaką przyniósł rok 1956 r., wzmacniała się swoboda w zakresie przedsięwzięć na polu badań naukowych. Usamodzielniło się szkolnictwo wyższe, zaczęto mówić o reorganizacji PAN i nawiązano współpracę z niektórymi krajami zachodnimi, co dotychczas było niemożliwe. Niestety w $1958 \mathrm{r}$. podczas kwietniowego posiedzenia KC PZPR dyskutowano już nad potrzebą zaostrzenia reżimu w dotychczasowej polityce wydawniczej, akcentowano głównie konieczność wzmożenia kontroli nad rynkiem książki, a to wiązało się z nasileniem działań aparatu cenzury i ograniczeniem swobody w zakresie prowadzenia badań naukowych.

Mimo licznych zabiegów ze strony władz, które w ostatecznym rozrachunku doprowadziły do sytuacji, kiedy kontroli podlegał każdy etap produkcji wydawniczej, działania te nie przyniosły oczekiwanych rezultatów, do rąk czytelników w dalszym ciągu trafiały bowiem niepożądane treści. Konieczność wycofywania ,szkodliwych” pozycji była dowodem na nieszczelność, a tym samym niedoskonałość prowadzonej przez władze polityki wydawniczej w sferze nauki.

Treść książki Doroty Degen, tutaj prezentowana jedynie w zarysie, powstała w oparciu o obszerną bazę źródłową i opracowania, stanowiące podstawę recenzowanej publikacji. Autorka przeprowadziła kwerendę przede wszystkim w pięciu archiwach krajowych, zaś materiały, na których się opierała w dużej mierze zostały wykorzystane po raz pierwszy. Na ogół nie doczekały się one jeszcze nawet opracowania, a większość uwzględnionych akt nadal figuruje pod tymczasowymi sygnaturami, co znacznie utrudnia kwerendę. Dorota Degen korzystała również ze znacznej liczby źródeł drukowanych takich, jak instrukcje wydawnicze, sprawozdania, przemówienia, wywiady, wspomnienia osób związanych z ruchem wydawniczym $w$ analizowanym przez nią okresie czy też zestawienia statystyczne. Warto przy tym zauważyć, że zwłaszcza te ostatnie wymagały wyjątkowej ostrożności i znajomości problematyki. Wprawdzie dane liczbowe są stosunkowo łatwo dostępne, to jednak metodologia klasyfikacji poszczególnych publikacji dość często się zmieniała. W takiej sytuacji, 
analizując je, należało zwrócić szczególną uwagę na tę kwestię, co autorce w pełni się udało.

Trudno także nie docenić znajomości wykorzystanej literatury przedmiotu. Choć na pozór jest ona bardzo bogata, nie zmienia to faktu, że książka Doroty Degen ma charakter pionierski. Wydana bowiem w latach 90. obszerna dwutomowa praca Piotra Hübnera ${ }^{1}$ naświetla głównie zagadnienia odnoszące się do samej polityki naukowej, zaś kwestie wydawnicze odgrywają w niej rolę drugorzędną. Jeśli natomiast chodzi o piśmiennictwo poświęcone polityce wydawniczej, dotychczas obejmowało ono zagadnienia ogólne lub dotyczące tylko beletrystyki ${ }^{2}$. Natomiast literatura na temat ruchu wydawniczego w sferze nauki miała charakter jedynie drobnych opracowań. Tymczasem Dorota Degen podjęła próbę spojrzenia na te zagadnienia kompleksowo - zarówno od strony problemów rynku książki, jak również od strony organizacji nauki. Pozwala to zauważyć niektóre mechanizmy niedostrzegalne przy odrębnym spojrzeniu na te zagadnienia. Przykładem jest chociażby wskazanie, jak dublowały się niektóre kompetencje przyznawane zarówno organom odpowiedzialnym za politykę wydawniczą, jak i tym, które sterowały organizacją nauki. W wyniku takich niejednoznacznych ustaleń następowało rozproszenie odpowiedzialności, co w dalszej konsekwencji podsycało i tak panujący już chaos w tym zakresie.

Przejmowaniu władzy przez komunistów i wprowadzaniu stalinizacji w nauce towarzyszyła spora dynamika zdarzeń. Kolejną przeszkodą, jaką musiała pokonać Dorota Degen, była rozproszona i niedostatecznie opracowana baza źródłowa. Jednak mimo tych trudności autorka zdołała przygotować czytelną i dobrze uargumentowaną syntezę zmian zachodzących w świecie nauki w latach 1944-1959.

Pomimo tych trudnych do przecenienia walorów omawianej publikacji, nie jest ona pozbawiona pewnych niedociągnięć. Jednym z nich jest brak wykazu skrótów, co w przypadku pracy, w której autorka operuje licznymi nazwami organizacji, często posługując się ich skrótami, stanowić może dość istotną przeszkodę w percepcji tekstu. Z kolei w zawartym w książce indeksie osobowym można łatwo wychwycić pewne błędy. Odesłanie bowiem czytelnika od nazwiska Abrahama Goldberga do Jerzego Borejszy,

1 P. Hübner, Polityka naukowa w Polsce w latach 1944-1953. Geneza systemu, t. 1-2, Wrocław-Warszawa-Kraków 1992.

2 Zob. np.: S. A. Kondak, Władza i wydawcy. Polityczne uwarunkowania produkcji ksiązek w Polsce w latach 1944-1949, Warszawa 1993; tenże, Papierowa rewolucja. Oficjalny obieg ksiązek w Polsce w latach 1948-1955, Warszawa 1999. 
sugerować może (chociaż nie musi), że jest to jedna i ta sama osoba, tymczasem Jerzy Borejsza to pseudonim syna Abrahama, czyli Beniamina Goldberga. Właściwe nazwisko tego ostatniego w głównym wykazie haseł osobowych zostało całkowicie pominięte, a figuruje jedynie przy uwzględnionym kryptonimie.

Robiąca ogólne bardzo dobre wrażenie - estetycznie wydana, czytelna i przejrzysta - rozprawa, nie pozbawiona jest także drobnych uchybień powstałych w trakcie końcowej pracy redakcyjnej, co oczywiście nie umniejsza wartości książki. Oddając ją do rąk czytelników, Dorota Degen przyczyniła się do znacznego wzbogacenia stanu wiedzy w zakresie powojennej polityki wydawniczej w sferze nauki. 